\title{
Knowledge Attitude and Practice of Parents Regarding Use of Antibiotics for Upper Respiratory Tract Infection Under Five Years of Children at Jinnah Hospital Lahore
}

\author{
Amber sarfraz ${ }^{1} \quad$ Adia Mukhtar $^{2} \quad$ Iqra Riaz $^{3}$ \\ 1.Department of Nursing, Superior University, 12 - A L Block, Block L Gulberg III, Lahore, Punjab 54000
}

\begin{abstract}
Objectives: To check parental knowledge, attitude and practice regarding use of antibiotics for upper respiratory tract infection under 5 years of age children.

Study Design: Cross-section, descriptive study.

Place and Duration: the study was done on admitted patient's parents regarding use of antibiotics for their children less than five years of age at Jinnah hospital peads ward from $15^{\text {th }}$ March to $31^{\text {st }}$ June 2020.

Methodology: Parent's knowledge attitude and practice checked for using antibiotics for upper respiratory tract infection in their under-five year's children. As a research tool questionnaire is used. Only parents of children below 5 years of age and admitted patients are included in these criteria. And people which are not willing to participate are excluded or more than 5 years children parents" people other than parents as grandparents. In sample size of 222 parents 68 were male respondents and 154 were female participants.

Results: 74 participants were higher education level 32 ere matric level .Parents 51.8\% have good knowledge $45.5 \%$ poor knowledge. $80 \%$ having good attitude and $88.3 \%$ with good practice.so education is related to good knowledge attitude and practice.

Conclusion: The people having satisfactory knowledge as well as attitude and good practice for use of antibiotics. Keywords: Upper respiratory tract infection (URTI) knowledge attitude and practice (KAP), Jinnah Hospital Lahore (JHL)
\end{abstract}

DOI: $10.7176 / \mathrm{JHMN} / 85-12$

Publication date: January $31^{\text {st }} 2021$

\section{Introduction}

Under five years of children upper respiratory tract infection is most leading cause of death. It is cause of children to hospitalize and creates high economic cost. We can say its leading cause of mortality and morbidity.(Dunea, Iordache \& Pohoata, 2016). The assessed rate of intense respiratory disease horribleness among children less than five years a long time in KSA was 50 percent detailed in health care centers. (El-Gilany \& Aref, 2000). A sizeable amount of antibiotics are consumed by children globally.in particularly upper respiratory tract infections, but most of the time all upper respiratory tract infection are caused by many viral specious. So, there is no or minimal benefits to use antibiotics. All knows the Importance of antibiotics is much when we see any case which can be treated through antibiotics. It is a biggest discovery of $20^{\text {th }}$ century as it decreases the disease and death rates. But in the past years its resistance has become a major health problem globally. In china USA and Kuwait, Saudi Arabia, India, Greece, and Cyprus study was done about usage of antibiotics, and development of its resistances. All over the world including Pakistan Pediatricians are commonly recommending antibiotics for upper respiratory infections in children. Upper respiratory tract infections may include flue, cough, otitis media, sinusitis, laryngitis, pharyngitis. In the case of otitis media and sinusitis and viral flue there is also no need of antibiotic because these are self-controlled. (Alluqmani et al., 2017).although some respiratory tract infections are caused by bacteria there is no need to use antibiotics they are self-settled. People believe that they can get well earlier through the use of antibiotics. Both doctors and parents are contributing in antibiotics abuse.(Butler, Hood, Verheij, \& Little, 2009) Antibiotic abuse is common in Pakistan. Parent's worldwide concern is increasing for bacterial resistance against antibacterial drugs. The use of antibiotics is increased in the world. (Teng, Leong, Aljunid, \& Cheah, 2004).This study is important in national intervention program so that we may monitor and lessen antibiotics misuse in children. This is also necessary to improve the public knowledge and change the attitude toward use of antibiotics. Parents may get knowledge about upper respiratory tract infection proper treatment and stop their practice of use of antibiotics for URTI; it may also improve their attitude. . About 20-50 percent use of antibiotics is inappropriate. (Wong, Blumberg \& Lowe, 2006). To meet the patient's expectation is a major factor for a doctor to recommend antibiotics and old experience of patient lead to it, so parents also want to use antibiotics for their children, and sometime they purchase from medical stores without current prescription.(Bauchner, Pelton, \& Klein, 1999) Regarding use of antibiotic and parents knowledge attitude and practices many studies are conducted in Palestine, Greece, India, and Malaysia .(Zarb et al., 2012) 


\section{Methodology}

Descriptive cross sectional design was used to check Knowledge attitude and practice of parents for use of antibiotics less than five years of children suffering from upper respiratory tract infection. This stud y conducted at Jinnah hospital Lahore on one month admitted patients in peads ward data is collected from parents of these babies are less than five years age admitted with upper respiratory tract infection. Population size was 500 and sample size was calculated by using Slovins Formula that was 222. Convenient sampling technique was used. Questionnaire was used as research tool which consists of four sessions. These four are biographical data (parents and children), knowledge, attitude and practice. In knowledge, attitude and practice session questions were based on likert scale (strongly agree, agree, neutral, disagree and strongly disagree). Biographical session consists of two sub sessions; parent's data have five questions and children data6 questions. Knowledge session consists of 7 questions, attitude 10 questions and practice 12 questions.

\subsection{Statistical Analysis}

SPSS version 20 was used for analysis. Data collected through questionnaire data was presented on writing. Percentage and frequency distribution was found out.

\section{Results}

Questionnaire was distributed 250 of which 25 were incomplete and 3 were misplaced so that was excluded.12 variables are find out in all questionnaire and result and response is based on these.

\subsection{Demographic information}

Response rate of mothers were high (69.4\%) than fathers (30.6\%). The characteristics of first session (demographic data) are presented in table 1.

\section{Table 1}

\begin{tabular}{|l|l|l|}
\hline Demographic characteristics & Number of respondents & Percent \\
\hline Male & 68 & $30.6 \%$ \\
Female & 154 & $69.4 \%$ \\
\hline No education Primary Matric & 69 & $31.1 \%$ \\
Higher & 47 & $21.1 \%$ \\
& 32 & $14.4 \%$ \\
\hline Income $<10000$ & 74 & $33.3 \%$ \\
\hline $10000-20000$ & 55 & $24.8 \%$ \\
220000 & 70 & $31.5 \%$ \\
\hline Male children & 97 & $43.7 \%$ \\
\hline Female children & 99 & $44.6 \%$ \\
\hline & 123 & $55.4 \%$ \\
\hline
\end{tabular}

\subsection{Knowledge, Attitude}

Participants which responds on ","antibiotics should be given to all patients who develops fever"' 95 (42.8\%) are agree, $8(3.6 \%)$ are neutral, $119(53.6 \%)$ are disagree. "most of upper respiratory tract infections are because of viruses antibiotics should not be given because they are viral origins "in this strongly agree are only $1(.5 \%)$. Agree are $100(45 \%)$, neutral are $6(2.7 \%)$ and disagree are very high $115(51.8 \%)$. Knowledge and attitude session results are shown in table 2. . "Do you think most of upper respiratory tract infections are resolved without antibiotics administration because they are self-limited?" response agree are $125(56.3 \%)$, neutral are $2(.9 \%)$ and disagree are 95(42.8\%). "Would you change your pediatrician because of not prescribing as many antibiotics as you think "agree are $42(18.9 \%)$, neutral $2(.9 \%)$ and disagree are $177(79.7 \%)$ as strongly disagree are $1(.5 \%)$. Figure 1 and figure 2 are presenting the percentages of parental knowledge and attitude. 
Table 2:

\begin{tabular}{|l|l|l|}
\hline \hline Knowledge and attitude of respondents & $\begin{array}{l}\text { Numbers of } \\
\text { respondents }\end{array}$ & Percentage \\
\hline Antibiotics are given all patients who develop fever Agree & 95 & $42.8 \%$ \\
\hline Neutral & 8 & $3.6 \%$ \\
Disagree & 119 & $53.6 \%$ \\
\hline Most of upper respiratory tract infection are viral origin & & \\
antibiotics should not be given. & 1 & \\
Strongly agree & 100 & $0.5 \%$ \\
Agree & 6 & $45 \%$ \\
Neutral & 115 & $2.7 \%$ \\
Disagree & & $51.8 \%$ \\
\hline Do you think that most of the upper respiratory tract infections & \\
are resolved without antibiotics administration because they are & & \\
self-limited? & & \\
Agree & 125 & 125 \\
Neutral & 2 & 2 \\
Disagree & 95 & 95 \\
\hline Would you change your pediatrician because of not prescribing as & & \\
many antibiotics as you think? & 42 & $18.9 \%$ \\
Agree & 2 & $0.9 \%$ \\
Neutral & 177 & $79.7 \%$ \\
Disagree & 1 & $0.5 \%$ \\
Strongly disagree &
\end{tabular}

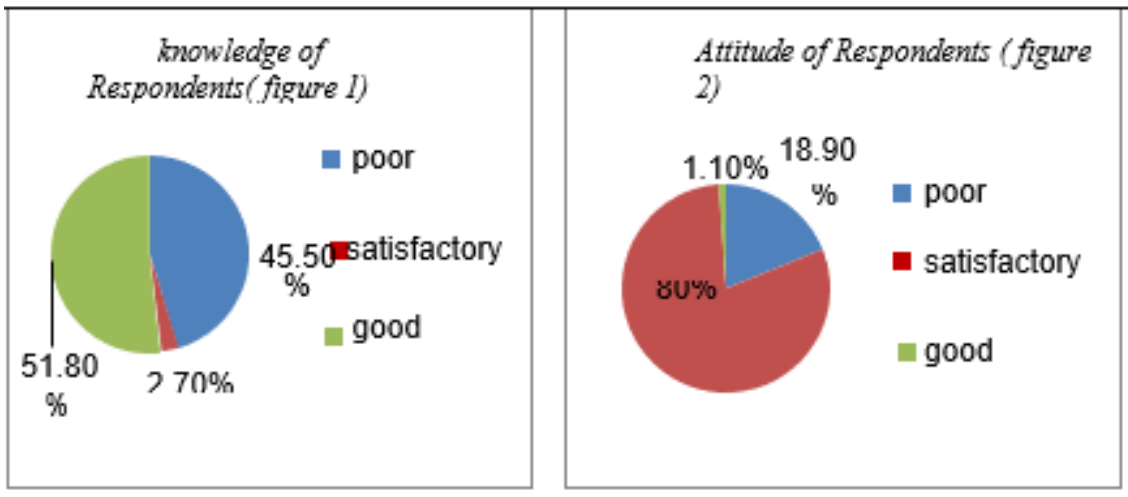

\subsection{Practice}

The practice session is analyzed with four variables and presented in table 4. "Do you believe that you are well informed about judicious antibiotics use? "In frequency and percentage .in this agree are 208(93.7\%) and dis agree are $14(6.3 \%)$. of parents on "How much do you consider the possible antibiotics adverse reaction when using them?"93(41.9\%) are agree, $2(.9 \%)$ are neutral and $127(57 \%)$ are disagree. the response of"' How often you asked your pediatrician whether or not the prescription of antibiotics is necessary?" agree 114(51.4\%), neutral are $2(.9 \%)$, disagree are $105(47.3 \%)$ and strongly disagree are $1(.5 \%)$. the response of members "How often your pediatrician recommended antibiotics on phone?" agree $25(11.3 \%)$, disagree are $196(88.3 \%)$ and strongly disagree are $1(.5 \%)$. 
Table 3

\begin{tabular}{|c|c|c|}
\hline Practice of respondents & $\begin{array}{ll}\text { Number } & \text { of } \\
\text { respondents }\end{array}$ & Percentage \\
\hline $\begin{array}{l}\text { Do you believe that you are well informed about judicious } \\
\text { antibiotics use? } \\
\text { Agree } \\
\text { Disagree }\end{array}$ & $\begin{array}{l}208 \\
14\end{array}$ & $\begin{array}{l}97.3 \% \\
6.3 \% \\
\end{array}$ \\
\hline $\begin{array}{l}\text { How much do you consider the possible antibiotics adverse reaction } \\
\text { when using them? } \\
\text { Agree } \\
\text { Neutral } \\
\text { Disagree }\end{array}$ & $\begin{array}{l}93 \\
2 \\
127\end{array}$ & $\begin{array}{l}41.9 \% \\
0.9 \% \\
57 \%\end{array}$ \\
\hline $\begin{array}{l}\text { How often you asked your pediatrician whether or not the } \\
\text { prescription of antibiotics is necessary? } \\
\text { Agree } \\
\text { Neutral } \\
\text { Disagree } \\
\text { Strongly disagree }\end{array}$ & $\begin{array}{l}114 \\
2 \\
105 \\
1\end{array}$ & $\begin{array}{l}51.4 \% \\
0.9 \% \\
47.3 \% \\
0.1 \% \\
\end{array}$ \\
\hline $\begin{array}{l}\text { How often you're pediatrician recommended } \\
\text { antibiotics on phone? } \\
\text { Agree } \\
\text { Disagree } \\
\text { Strongly disagree }\end{array}$ & $\begin{array}{l}25 \\
196 \\
1\end{array}$ & $\begin{array}{l}11.3 \% \\
88.3 \% \\
0.5 \%\end{array}$ \\
\hline
\end{tabular}

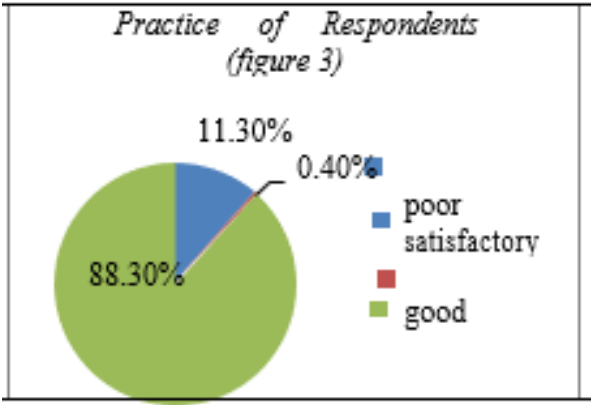

\section{Discussion}

The study is done to analyses the parents knowledge attitude and practice about unnecessary usage of antibiotics for upper respiratory tract infections in children which are aged below 5years and developing respiratory tract infection repeatedly. That's why there parents are concerned use of antibiotics and requesting their pediatricians to recommend more antibiotics and which have experience as their children recover more rapidly when antibiotics are used in these case, but they also know the antibiotics are for bacterial infections and mostly upper respiratory tract infection are of viral origins but they believe that the roll of antibiotics is good in treating such infections. The respondents are male 68(30.6\%) and female participants are 154(69.4\%).there were more female participants then female in admitted patients. The education status of the respondents was, no education $69(31.1 \%)$, respondents with primary education was $47(21.2 \%)$, matric qualified parents were $32(14.4 \%)$ and parents with higher education were $74(33.3 \%) \ldots$ The income status of respondents was as $<10,000 /$ - were $55(24.8 \%)$ and parents of income group between 10,000/--20,000/- were 70(31.5\%) and more than 20,000/earning were $97(43.7 \%)$. Gender of children was checked which were admitted in hospital of their parents were respondents.in these 99 were male $(44.6 \%)$ and female children were $123(55.4 \%) \ldots$ the results showing that $51.8 \%$ having good knowledge $45.5 \%$ with poor knowledge attitude $80 \%$ was satisfactory and good practice were $80 \%$. Similar study was done on Parent's knowledge attitude and practice on antibiotics use by children on different areas of Saudi Arab, total 544 parents were respondent $75 \%$ male and others were female $68.6 \%$ purchased antibiotics without prescription. $34 \%$ purchased after prescription. $7.2 \%$ not used antibiotics. 505 take advice from their doctor to use antibiotics. It. (Al-Ayed, 2019)In DUBAI parental views of antibiotics use in children with upper respiratory tract infections .only 10\% says antibiotics can cause harm. $33 \%$ says antibiotics can be give if they develop fever regardless of cause. $48 \%$ were aware about respiratory infections are caused by virus, without medical advice they use antibiotics because lack of money. $83 \%$ based on pharmacist recommendations $68 \%$ using previously prescribe medicines $66.2 \%$.(Hammour, Al-Saleh, \& Hammour, 
2019)Parent's self-directed practice for antibiotics use study done in Holy Makah Saudi Arabia results were 95\% mothers respond, there were no health insurance of $67 \%$ to bear the costs of medicine $74 \%$ low income people. Doctor is the source of information $70 \%$ believed.URTI is caused by virus only $8 \%$ knows that. For cough nasal discharge and sore throat and fever 53\% expect to treat their children with antibiotics. And they are using Augmentin, calamox, amoxil, erythromycin for their purpose.(Faidah et al., 2019).

\section{Conclusion}

As 74 respondents were higher education level and 32 with matric level .The findings of this study show that parents have satisfactory knowledge and attitude and good practice about use of antibiotics.

\subsection{Research recommendations}

In this research we come to know that there is relationship between literate parents and their knowledge about antibiotics. So it is recommended that our government should take steps to improve overall education level of parents are should be a topic in regular subjects about antibiotics and their uses.

\subsection{Acknowledgement}

Questionnaire used in this article is adopted from Greece article published in 2011 .The authors are thankful to superior university department of nursing for providing this chance .

\section{References}

1. Agarwal, S., Yewale, V. N., \& Dharmapalan, D. (2015). Antibiotics use and misuse in children: a knowledge, attitude and practice survey of parents in India. Journal of clinical and diagnostic research: JCDR, 9(11), SC21.

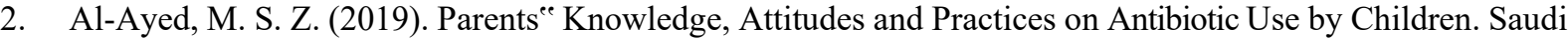
journal of medicine \& medical sciences, 7(2), 93.

3. Alkhaldi, S. M., Al-Mahmoud, M. F., \& Kanaan, H. (2015). Mothers ${ }^{\text {ee }}$ knowledge, attitudes, and practices of antibiotic use for children in Jordan. J Med J, 49(4), 215- 226.

4. Alluqmani, M. F., Aloufi, A. A., Abdulwahab, A. M. A., Alsharif, A. I. K., AlShathri,A. A. A., AlShehri, M. S., ... Alshammari, B. J. I. (2017). Knowledge, attitude and practice of mothers on acute respiratory infection in children under five years in Saudi Arabia, 2017. The Egyptian Journal of Hospital Medicine, 69(2), 19591963.

5. Bauchner, H., Pelton, S. I., \& Klein, J. O. (1999). Parents, physicians, and antibiotic use. Pediatrics, 103(2), 395-401.

6. Bham, S. Q., Saeed, F., \& Shah, M. A. (2016). Knowledge, Attitude and Practice of mothers on acute respiratory infection in children under five years. Pakistan journal of medical sciences, 32(6), 1557.

7. Butler, C., Hood, K., Verheij, T., \& Little, P. (2009). Mel bye H, Nuttall J, Kelly MJ, Mölstad S, GodyckiCwirko M, Almirall J, Torres A, Gillespie D, Rautakorpi U, Coenen S, Goossens H. Variation in antibiotic prescribing and its impact on recovery in patients with acute cough in primary care: prospective study in 13 countries. BMJ, 338, b2242.

8. Cals, J. W., Boumans, D., Lardinois, R. J., Gonzales, R., Hopstaken, R. M., Butler, C. C., \& Dinant, G.-J. (2007). Public beliefs on antibiotics and respiratory tract infections: an internet-based questionnaire study. $\mathrm{Br}$ J Gen Pract, 57(545), 942-947.

9. Dekker, A. R., Verheij, T. J., Broekhuizen, B. D., Butler, C. C., Cals, J. W., Francis,N. A., ... Zuithoff, N. P. (2018). Effectiveness of general practitioner online training and an information booklet for parents on antibiotic prescribing for children with respiratory tract infection in primary care: a cluster randomized controlled trial. Journal of Antimicrobial Chemotherapy, 73(5), 1416-1422.

10. Donmez, S., Gungor, K., \& Gov, P. (2018). Knowledge, attitude and practice of self- medication with antibiotics among nursing students. Int J Pharmacol, 14(1), 136-143.

11. Dunea, D., Iordache, S., \& Pohoata, A. (2016). Fine particulate matter in urban environments: a trigger of respiratory symptoms in sensitive children. International journal of environmental research and public health, 13(12), 1246.

12. El-Gilany, A.-H., \& Aref, Y. (2000). Failure to register for antenatal care at local primary health care centers. Annals of Saudi medicine, 20(3-4), 229-232.

13. Faidah, H. S., Haseeb, A., Lamfon, M. Y., Almatrafi, M. M., Almasoudi, I. A., Cheema, E., . .. Saleem, F. (2019). Parentse self-directed practices towards the useofantibiotics for upper respiratory tract infections in Makkah, Saudi Arabia. BMC pediatrics, 19(1), 